\title{
Transgenic Mice Overexpressing Amyloid Precursor Protein Exhibit Early Metabolic Deficits and a Pathologically Low Leptin State Associated with Hypothalamic Dysfunction in Arcuate Neuropeptide Y Neurons
}

\author{
[D Makoto Ishii, ${ }^{1}$ Gang Wang, ${ }^{1}$ Gianfranco Racchumi, ${ }^{1}{ }^{\oplus}$ Jonathan P. Dyke, ${ }^{2}$ and Costantino Iadecola ${ }^{1}$ \\ ${ }^{1}$ Feil Family Brain and Mind Research Institute and ${ }^{2}$ Department of Radiology, Weill Cornell Medical College, New York, New York 10065
}

\begin{abstract}
Weight loss is a prominent early feature of Alzheimer's disease $(\mathrm{AD})$ that often precedes the cognitive decline and clinical diagnosis. While the exact pathogenesis of $\mathrm{AD}$ remains unclear, accumulation of amyloid- $\beta(\mathrm{A} \beta)$ derived from the amyloid precursor protein (APP) in the brain is thought to lead to the neuronal dysfunction and death underlying the dementia. In this study, we examined whether transgenic mice overexpressing the Swedish mutation of APP (Tg2576), recapitulating selected features of AD, have hypothalamic leptin signaling dysfunction leading to early body weight deficits. We found that 3-month-old Tg2576 mice, before amyloid plaque formation, exhibit decreased weight with markedly decreased adiposity, low plasma leptin levels, and increased energy expenditure without alterations in feeding behavior. The expression of the orexigenic neuropeptide Y (NPY) in the hypothalamus to the low leptin state was abnormal at basal and fasting conditions. In addition, arcuate NPY neurons exhibited abnormal electrophysiological responses to leptin in Tg2576 hypothalamic slices or wild-type slices treated with $\mathrm{A} \beta$. Finally, the metabolic deficits worsened as $\mathrm{Tg} 2576$ mice aged and amyloid burden increased in the brain. These results indicate that excess $\mathrm{A} \beta$ can potentially disrupt hypothalamic arcuate NPY neurons leading to weight loss and a pathologically low leptin state early in the disease process that progressively worsens as the amyloid burden increases. Collectively, these findings suggest that weight loss is an intrinsic pathological feature of $A \beta$ accumulation and identify hypothalamic leptin signaling as a previously unrecognized pathogenic site of action for $\mathrm{A} \beta$.
\end{abstract}

Key words: Alzheimer's disease; amyloid; hypothalamus; leptin; NPY

\section{Introduction}

Alzheimer's disease $(\mathrm{AD})$ is pathologically characterized by amyloid plaques, composed of amyloid- $\beta(\mathrm{A} \beta)$ peptides, and by neurofibrillary tangles, composed of hyperphosphorylated tau (Querfurth and LaFerla, 2010). Accumulation over time of $\mathrm{A} \beta 1-40$ and $\mathrm{A} \beta 1-42$ derived from the amyloid precursor protein (APP) in the brain is thought to lead to the neuronal dysfunction and death underlying the dementia. Increasing evidence suggests that $\mathrm{AD}$ begins several years before the cognitive decline

Received March 3, 2014; revised May 16, 2014; accepted June 5, 2014.

Author contributions: M.I., G.W., J.P.D., and C.I. designed research; M.I., G.W., G.R., and J.P.D. performed research;M.I. contributed unpublished reagents/analytic tools; M.I., G.W., and J.P.D. analyzed data;M.I. and C.I. wrote the paper.

This work was supported by the Feil Family Foundation, National Institutes of Health Grant NS37853 to C.I., a Zenith Fellow Award from the Alzheimer's Association to C.I., and the Leon Levy Foundation to M.I. M.I. holds a Leon Levy Neuroscience Fellowship. We thank Dr. Jeffrey Friedman for helpful discussions and use of facilities and equipment; Dr. Steven Paul for helpful discussions; Dr. Henning Voss and Mr. Eric Aronowitz for assistance with MRI studies; Dr. Ping Zhou and Ms. Huihong Li for maintenance of mouse colonies; Mr. Corey Anderson for assistance with generating soluble oligomeric Ab1-42; and Ms. Alicia Savage-Nieves, Sophy Aguilar, and Karen Carter for administrative support.

The authors declare no competing financial interests.

Correspondence should be addressed to Dr. Costantino ladecola, Feil Family Brain and Mind Research Institute, Weill Cornell Medical College, 407 E. 61st Street, RR-303, New York, NY 10065. E-mail: coi2001@med.cornell.edu. DOI:10.1523/JNEUROSCI.0872-14.2014

Copyright $\odot 2014$ the authors $\quad 0270-6474 / 14 / 349096-11 \$ 15.00 / 0$
(Bateman et al., 2012), stressing the need to intervene earlier in AD, before significant damage occurs (Sperling et al., 2011). Therefore, it has become increasingly important to gain better insights into the pathological processes occurring at the earliest stages of AD.

Body weight loss is a prominent clinical feature of $\mathrm{AD}$, correlating with disease severity and increased mortality (White et al., 1998). Dementia causing alterations in feeding behavior could potentially explain weight loss during late stages of AD. However, several studies have reported that one of the earliest manifestations in preclinical $\mathrm{AD}$ is accelerated early weight loss (BarrettConnor et al., 1996; Buchman et al., 2005; Stewart et al., 2005; Johnson et al., 2006). Increased burden of AD biomarkers, such as CSF $A \beta 1-42$ levels in cognitively normal individuals, were also associated with weight loss, thereby linking $\mathrm{A} \beta$ pathology to weight loss in preclinical AD (Vidoni et al., 2011). Thus, weight loss likely represents an intrinsic feature of AD that arises early in the disease process.

The exact mechanisms underlying the weight loss in preclinical $\mathrm{AD}$ are unknown, but early $\mathrm{A} \beta$ accumulation could conceivably disrupt brain circuits regulating body weight. Leptin is an adipocyte-derived hormone that acts as the negative afferent loop in the regulation of body weight mainly through hypothalamic pathways (Zhang et al., 1994; Gautron and Elmquist, 2011). Lep- 
tin receptors are also expressed in the cortex and hippocampus and have been implicated in learning and memory (Harvey, 2013). Epidemiological studies have also shown a correlation between low plasma leptin levels and increased risk of developing $\mathrm{AD}$ or age-related cognitive decline (Power et al., 2001; Holden et al., 2009; Lieb et al., 2009; Johnston et al., 2014). Furthermore, studies in transgenic mice overexpressing APP have shown that exogenous leptin reduces, whereas leptin deficiency exacerbates amyloid pathology in these mice (Greco et al., 2010; Takeda et al., 2010). These observations, collectively, raise the possibility that altered leptin signaling plays an early role in $\mathrm{AD}$, but the cellular and molecular bases for this effect remain to be established.

In this study, we tested the hypothesis that excess $\mathrm{A} \beta$ causes hypothalamic leptin signaling dysfunction resulting in early weight loss. Using a transgenic mouse model overexpressing the Swedish APP mutation (Tg2576), we found that there is body weight and metabolic deficits before amyloid plaque formation, an effect associated with low plasma leptin and marked dysfunction in leptin-responsive hypothalamic arcuate neuropeptide $\mathrm{Y}$ (NPY) neurons. Our findings suggest that APP overexpression and/or $\mathrm{A} \beta$ accumulation causes early alterations in leptinresponsive hypothalamic neurons involved in regulating body weight and provide a potential mechanism for the weight loss associated with preclinical AD.

\section{Materials and Methods}

Animals. All procedures were approved by the Institutional Animal Care and Use Committee of Weill Cornell Medical College and Rockefeller University. Experiments were performed in $A P P_{\text {swe }}$ transgenic (Tg2576) mice with the transgene human APP695 containing the Swedish double mutation K670N, M671L driven by a hamster prion protein promoter (RRID:MGI_MGI:3710766) (Hsiao et al., 1996). All Tg2576 mice were derived from an in-house colony maintained on the original hybrid C57BL/6J-SJL line. Sex- and age-matched wild-type (WT) littermate mice were used as controls for all experiments. All mice were housed in climate controlled $12 \mathrm{~h}$ light-dark cycle rooms and had free access to water and standard rodent chow (LabDiet, catalog \#5053) unless otherwise specified. After weaning, female $\mathrm{Tg} 2576$ mice were group-housed, but male mice were individually caged because of aggressive behavior. For NPY-GFP mice, we used the previously well-characterized BAC transgenic NPY-hrGFP mice line (B6.FVB-Tg(NPY-hrGFP)1Lowl/J, The Jackson Laboratory, catalog \#006417, RRID:IMSR_JAX:006417) (van den Pol et al., 2009). To generate Tg2576 mice with GFP labeling in NPY neurons, we crossed male Tg2576 mice with female NPY-GFP mice to produce hemizygous NPY-GFP mice with or without a copy of the $A P P_{\text {swe }}$ transgene.

Blood/plasma and tissue analysis in Tg2576 mice. For tissue and plasma analysis, all mice were killed by $\mathrm{CO}_{2}$ asphyxiation between $11 \mathrm{AM}$ and 1 PM or 4-6 h after lights on. Blood was obtained by transcardiac puncture with an EDTA-treated needle and measured immediately for glucose levels with a commercial glucometer (AgaMatrix). Plasma was obtained from the blood samples by centrifugation of the EDTA-treated blood and then stored at $-20^{\circ} \mathrm{C}$ in aliquots to avoid freeze-thaw. Plasma leptin and insulin levels were measured using commercially available ELISA kits (R\&D Systems catalog \#MOB00 and ALPCO Diagnostics catalog \#80INSMSU-E01, respectively). After the blood was removed from each mouse, the brain was immediately removed and submerged into ice-cold PBS. The hypothalamus was then carefully dissected, snap-frozen in liquid nitrogen, and stored at $-80^{\circ} \mathrm{C}$ until use. For brain $\mathrm{A} \beta 1-42$ measurements, SDS-soluble $A \beta 1-42$ were measured in hemisected brains of Tg2576 mice at various ages ( $n=2$ or 3 per group) by ELISA as previously described (Park et al., 2008).

Food intake and fasting studies. Adult mice were individually housed and acclimated for over a week before food intake measurements $(n=$ 9-12 per group). Each day of the experiment, standard rodent chow
Table 1.PCR primers used in the study ${ }^{a}$

\begin{tabular}{|c|c|c|c|}
\hline Gene & $\begin{array}{l}\text { MGI } \\
\text { symbol }\end{array}$ & Forward primer & Reverse primer \\
\hline APP & App3 & TCTCGTTCCTGACAAGTGCAA & GCAAGTTGGTACTCTTCTCACTG \\
\hline Leptin receptor & Lepr & TTGTGTCCTACTGCTCGGAAC & TGTTTCAGGCTTTTGGAAATTCAGT \\
\hline NPY & Npy & CCGCCACGATGCTAGGTAAC & CAGCCAGAATGCCCAAACAC \\
\hline AgRP & Agrp & TTTGGCGGAGGTGCTAGAT & AAGGTACCTGCTGTCCCAAG \\
\hline POMC & Pomc & AGGCGACGGAAGAGAAAAGA & AGATTGGAGGGACCCCTGT \\
\hline CART & Cartp & CCCGAGCCCTGGACATCTA & GCTTCGATCTGCAACATAGCG \\
\hline HPRT & Hprt & AGTGTTGGATACAGGCCAGAC & CGTGATTCAAATCCCTGAAGT \\
\hline
\end{tabular}

${ }^{a}$ MGI, Mouse gene identifier.

(\#5053, LabDiet) was carefully measured and checked for food spillage to obtain a daily food intake per animal. The average food intake over seven consecutive days was calculated and recorded for each animal. For fasting studies, all mice were group-housed. Food was removed from the cages at 10 AM for the next $48 \mathrm{~h}$. Water was freely available; otherwise, cage conditions were identical to normal "fed" conditions. Mice were weighed daily and checked for overt signs of distress or health problems throughout the fasting period. None of the mice showed evidence of any significant health problems during the fast. All mice were killed $48 \mathrm{~h}$ after the fast was started.

Metabolic rate analysis. Metabolic rate was measured using a commercial indirect calorimeter system with metabolic cages (Oxymax system, Columbus Instruments) as previously described (Ishii et al., 2003). All mice ( $n=5$ per group) were acclimated for at least $2 \mathrm{~d}$ in the metabolic cages before recording and had free access to food and water. $\mathrm{O}_{2}$ levels from each cage were continually recorded at $8 \mathrm{~min}$ intervals and compared with the reference room air. Resting $\mathrm{O}_{2}$ consumption was defined as all measurements when no locomotor activity (beam breaks) was detected in the metabolic cage.

Body composition analysis. All mice ( $n=5$ or 6 per group) were anesthetized with $2 \%-3 \%$ isoflurane for induction and $1 \%-2 \%$ for maintenance and carefully immobilized on a 7.0 Tesla 70/30 MRI small animal scanner (Bruker). A T1-Weighted Rapid Acquisition with Refocused Echoes (RARE) sequence was acquired with repetition (TR) and echo (TE) times of 1975 and $10 \mathrm{~ms}$, respectively. This yielded a total of 60 slices with an isotropic voxel resolution of $0.4 \mathrm{~mm} \times 0.4 \mathrm{~mm} \times 0.4 \mathrm{~mm}$ and 4 averages. Whole-body MR spectroscopy was acquired using a single pulse sequence with a $25,000 \mathrm{~Hz}$ sweep width, 2048 points, 32 averages, and a $5000 \mathrm{~ms}$ repetition time. Data were read into the in-house written XSOS Spectroscopy Analysis Package (D. Shungu and X. Mao) for analysis. Spectra were Fourier transformed, phased, and a baseline correction performed. Peak areas of both water and lipid were integrated within fixed frequency windows as previously described (Mystkowski et al., 2000). The resulting peak area of water and lipid was used to calculate the whole-body lipid and water fractions. Per previously validated MR spectra analysis for body composition in mice (Mystkowski et al., 2000), lean mass was calculated according to the equation, lean mass $=0.38 \times$ peak area of water. Because total mass $=$ total fat mass + total water mass + total lean mass, percent fat was calculated by $\%$ fat $=100 \times$ peak area lipid/(peak area water + peak area lipid $+0.38 \times$ peak area of water). Total fat mass was calculated by multiplying percent fat by the body weight at the time of MR analysis. Lean and water (total and percent) masses for each mouse were calculated in a similar fashion.

Quantitative PCR. Quantitative PCR was conducted as previously described (Jackman et al., 2013). Briefly, total RNA was extracted from the tissue by Trizol reagent (Invitrogen) and dissolved in DEPC-treated nuclease free water. A total of $1 \mu \mathrm{g}$ of total RNA was reverse-transcribed to cDNA using oligo dT primers (Thermo Scientific). Quantitative determination of gene expression was performed on a Chromo 4 detector (Peltier thermal cycler, MJ Research) using a two-step cycling protocol. Primers are listed in Table 1. A total of $3 \mu$ l of diluted cDNA (1:10) was amplified by Maxima SYBR green qPCR supermix UDG (Thermo Scientific). The reactions were incubated at $50^{\circ} \mathrm{C}$ for $2 \mathrm{~min}$ and then $95^{\circ} \mathrm{C}$ for $10 \mathrm{~min}$. A PCR cycling protocol consisting of $15 \mathrm{~s}$ at $95^{\circ} \mathrm{C}$ and $1 \mathrm{~min}$ at $60^{\circ} \mathrm{C}$ for 45 cycles was required for quantification. Relative expression levels were calculated by the $\Delta \Delta \mathrm{C}_{\mathrm{T}}$ method (Livak and Schmittgen, 
2001). Quantities of all targets in test samples were normalized to the mouse housekeeping hypoxanthine-guanine phophoribosyltransferase gene, and values were correlated to WT samples or WT fed samples for fasting studies as appropriate.

Immunohistochemistry. Mice were deeply anesthetized with sodium pentobarbital and transcardially perfused with $0.1 \mathrm{M}$ phosphate buffer (PB) followed by fresh ice-cold 4\% PFA. Brains were removed and postfixed in same fixative overnight at $4^{\circ} \mathrm{C}$. The $40 \mu \mathrm{m}$ coronal brain sections were cut using a Leica VT1000s vibratome (Leica Microsystems) and stored in storage solution (30\% sucrose and $30 \%$ ethylene glycol in $0.1 \mathrm{M} \mathrm{PB}$ ) at $-20^{\circ} \mathrm{C}$ until analysis. For immunohistochemistry studies $(n=2-3$ per group), free-floating brain sections were removed from storage solution, washed in PBS, incubated in $70 \%$ formic acid at room temperature for $15 \mathrm{~min}$, washed in PBS, and then treated with $\mathrm{H}_{2} \mathrm{O}_{2}$ to quench endogenous peroxidase activity. Sections were then washed in PBS and blocked in M.O.M. blocking reagent (Vector, catalog \#PK-2200) diluted in $0.3 \%$ Triton X-100 in PBS at room temperature for $1 \mathrm{~h}$, followed by incubation in mouse monoclonal $\mathrm{A} \beta$ 4G8 antibody (1:2000, Covance, catalog \#SIG-39220-200, RRID: AB_10174824) overnight at $4^{\circ} \mathrm{C}$ with gentle shaking. Sections were washed and then incubated in donkey biotinylated anti-mouse secondary antibody (1:400, Jackson ImmunoResearch Laboratories, catalog $\# 715-065-150)$ at room temperature for $1 \mathrm{~h}$, washed, incubated in $\mathrm{ABC}$ (Vector, catalog \#PK-2200) for $30 \mathrm{~min}$, washed, and then developed with DAB (Sigma-Aldrich) for $6 \mathrm{~min}$. Stained sections were mounted on gelatin coated slides, dried, and dehydrated with increasing concentration of ethanol then xylene, and finally coverslipped with DPX mounting reagent (Sigma-Aldrich) before visualization under a light microscope (Eclipse e200, Nikon) equipped with a digital camera (Optixcam Summit, Microscope Store).

Preparation of hypothalamic slices and whole-cell patch-clamp studies. Three- to 5-week-old NPY-GFP hemizygous mice with or without a copy of the $\mathrm{APP}_{\text {swe }}$ transgene were used in all electrophysiology experiments ( $n=4-9$ per group). The mice were anesthetized with $2 \%$ isoflurane, and their brains were rapidly removed and immersed into ice-cold sucrose (s)-ACSF composed of (in $\mathrm{mm}$ ) the following: 248 sucrose, 26 $\mathrm{NaHCO}_{3}, 1 \mathrm{NaH}_{2} \mathrm{PO}_{4}, 3 \mathrm{KCl}, 5 \mathrm{MgSO}_{4}, 0.5 \mathrm{CaCl}_{2}, 10$ glucose, gassed with $95 \% \mathrm{O}_{2}$ and $5 \% \mathrm{CO}_{2}$, pH 7.3. Coronal slices (200 $\mu$ m thickness) containing the hypothalamic arcuate nuclei were cut using a Leica VT1000s vibratome (Leica Microsystems) and stored in a self-designed chamber containing lactic acid (l)-ACSF composed of (in $\mathrm{mm}$ ) the following: $124 \mathrm{NaCl}, 26 \mathrm{NaHCO}_{3}, 5 \mathrm{KCl}, 1 \mathrm{NaH}_{2} \mathrm{PO}_{4}, 2 \mathrm{MgSO}_{4}, 2 \mathrm{CaCl}_{2}, 10$ glucose, 4.5 lactic acid, gassed with $95 \% \mathrm{O}_{2}$ and $5 \% \mathrm{CO}_{2}$ and $\mathrm{pH} 7.4$, at $32^{\circ} \mathrm{C}$ for $1 \mathrm{~h}$. After $1-2 \mathrm{~h}$ recovery, the hypothalamic slice was transferred to a glass-bottom recording chamber (P-27; Warner Instrument) mounted on an E600 epifluorescence microscope (Nikon). The slices were continuously perfused with the oxygenated l-ACSF at $2 \mathrm{ml} / \mathrm{min}$ at room temperature $\left(24^{\circ} \mathrm{C}-28^{\circ} \mathrm{C}\right)$. Under the microscope equipped with $40 \times$ water-immersion lens and the FITC filter (Chroma Technology), the arcuate nuclei were identified in the ventromedial portion near the base of the third ventricle with GFP-labeled arcuate NPY neurons in slices consistently displaying intense green fluorescence and the visualized whole-cell recordings were performed on GFP-labeled neurons (Wang et al., 2013). The patch glass electrode was pulled using borosilicate capillaries (OD $1.5 \mathrm{~mm} / \mathrm{ID} 0.86 \mathrm{~mm}$; World Precision Instruments) and P-80 micropipette puller (Sutter Instruments). The resistance of the pipette was 5-7 $\mathrm{M} \Omega$ when filled with an intracellular solution containing (in $\mathrm{mm}$ ) the following: $130 \mathrm{~K}$-gluconate, $10 \mathrm{NaCl}, 1.6 \mathrm{MgCl}_{2}, 0.1 \mathrm{EGTA}$, 10 HEPES, and $2 \mathrm{Mg}$-ATP, adjusted to $\mathrm{pH}$ 7.3. The current-clamp recordings were performed in GFP-positive arcuate neurons using an Axopatch 200A amplifier (filtered at $2 \mathrm{kHz}$, digitized at $10 \mathrm{kHz}$ ) and Digidata 1320A (Molecular Devices). After a giga $\Omega$ seal formation, brief negative pressure was further applied to obtain the whole-cell configuration. The recording began with the membrane test for monitoring the access resistance and the membrane, which was continuously monitored through the recording. Only those cells in which access resistance was stable (change $<10 \%$ ) were included in data analysis. Stable baseline recordings were achieved before local application of vehicle (PBS or RPMI-1640 media buffer, Sigma-Aldrich), leptin (100 nM, Sigma-Aldrich, Cat \#L3772), or octanoylated (active) ghrelin (100 nm, Phoenix Pharmaceuticals, Cat \#031-31) to the bath. For $\mathrm{A} \beta$ experiments, stable baseline recordings were achieved then oligomeric A $\beta 1-42(10,30$, and $100 \mathrm{~nm}$, rPeptide, catalog \#A-1002) was locally applied to the bath and allowed to incubate for $15 \mathrm{~min}$ before subsequent application of leptin (100 nM) or ghrelin (100 nM). The membrane potential and the frequency of spontaneous spikes were analyzed offline using a Window pClamp 8 (Molecular Devices) and MiniAnalysis (Synaptosoft), separately. The liquid junction potentials were corrected during offline analysis.

Preparation of oligomeric $A \beta 1-42$. Soluble oligomeric $A \beta 1-42$ was freshly prepared from lyophilized solid human synthetic A $\beta 1-42$ (rPeptide, catalog \#A-1002) as previously described with minor modifications (Ryan et al., 2010). Briefly, lyophilized A $\beta 1-42$ was suspended in $1,1,1$, 3,3,3 hexafluoro-2-propanol (Sigma-Aldrich) to $1 \mathrm{~mm}$ using a gastight syringe. The peptide solution was aliquoted and lyophilized using a Speed-Vac. Dried peptide was stored at $-80^{\circ} \mathrm{C}$ until additional processing. Before the electrophysiology experiments, dried peptide was resuspended in anhydrous DMSO (Sigma-Aldrich), bath-sonicated for $10 \mathrm{~min}$, diluted to $100 \mu \mathrm{M}$ with PBS or RPMI-1640 media (Sigma-Aldrich), and allowed to oligomerize by incubation at $4^{\circ} \mathrm{C}$ for $24 \mathrm{~h}$. After incubation, the peptide solution was centrifuged to remove insoluble aggregates. The supernatant containing the soluble oligomeric $\mathrm{A} \beta 1-42$ was removed and used for the electrophysiology experiments.

Statistics. All data are presented as mean \pm SEM and analyzed using Prism version 5 (GraphPad Software). Two-group comparisons were analyzed by the two-tailed $t$ test. Multiple comparisons were evaluated by ANOVA followed by post hoc Tukey comparison. Differences were considered statistically significant for $p$ values $<0.05$.

\section{Results}

Transgenic mice overexpressing APP have decreased adiposity and low plasma leptin before amyloid plaque formation

We used Tg2576 mice because they slowly accumulate $A \beta$ and require several $(6+)$ months before behavioral abnormalities and amyloid plaques develop (Hsiao et al., 1995; Kawarabayashi et al., 2001). This allowed us to study adult mice in the earliest presymptomatic stages of $\mathrm{A} \beta$ pathology. Consistent with previous 
A
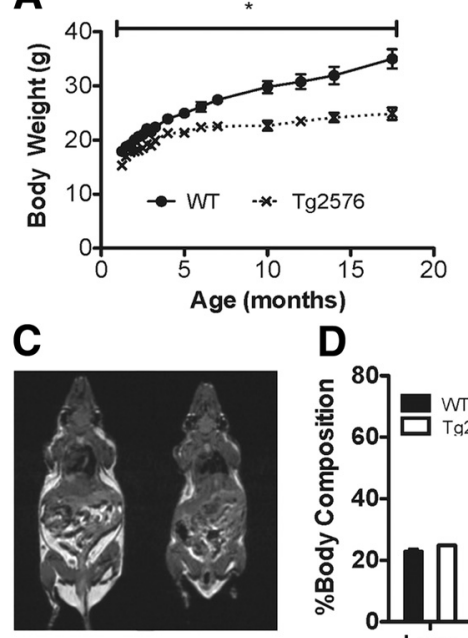

F

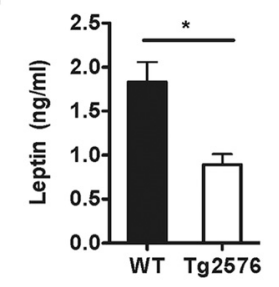

D

G
B
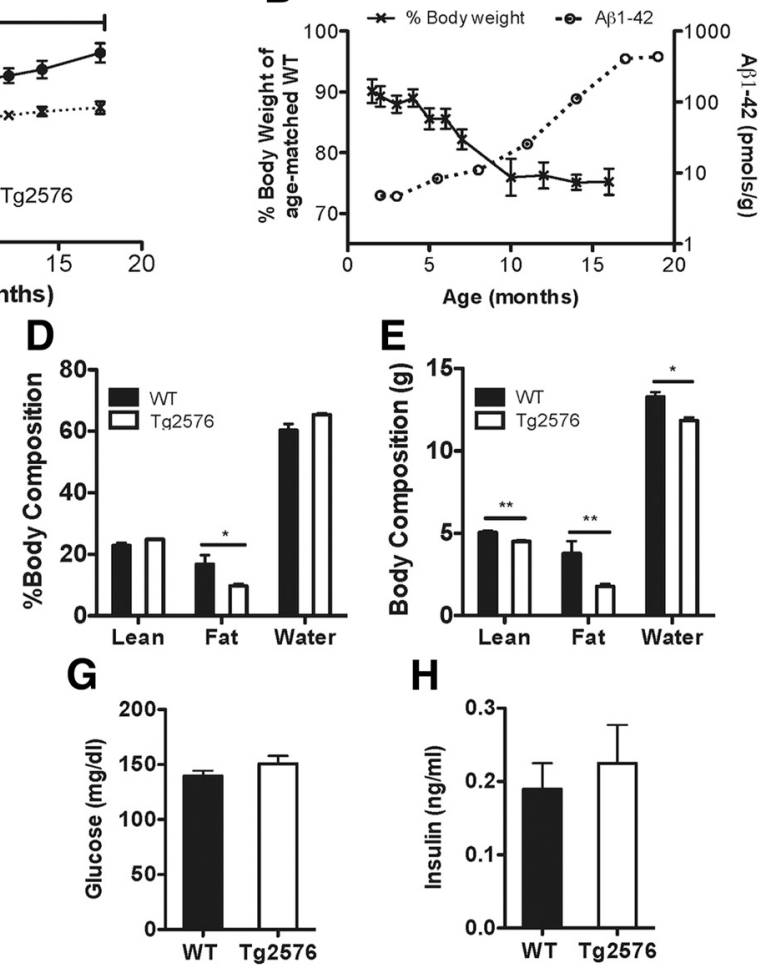

E

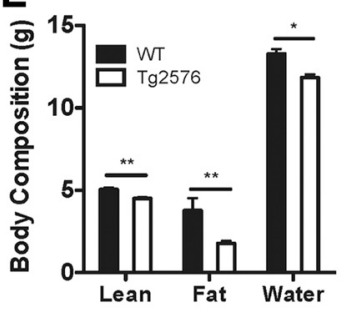

H

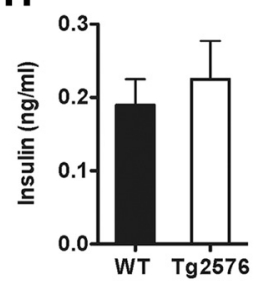

Figure 2. Tg2576 mice have decreased adiposity and low plasma leptin levels before amyloid plaque formation. $\boldsymbol{A}$, Body weight curve showing significantly lower body weights in female Tg2576 mice compared with WT mice ( $n=4-10$ per group). $\boldsymbol{B}$, Increasing brain $A \beta 1-42$ burden correlates with worsening body weight deficits (\% body weight of age-matched WT littermates) in $\operatorname{Tg} 2576$ mice ( $n=2$ or 3 per group for brain amyloid measurements; $n=4-10$ per age for body weight measurements). $C$, Representative T1-weighted MR image showing decreased adipose tissue mass (bright, hyperintense signal) in 3-month-old female Tg2576 mice compared with WT mice. D, E, Markedly decreased adiposity in 3-month-old Tg2576 mice as demonstrated by MR spectroscopy body composition analysis ( $n=5$ per group). $\boldsymbol{F}, \operatorname{Tg} 2576$ mice have significantly decreased plasma leptin levels ( $n=12-14$ per group). $\mathbf{G}, \boldsymbol{H}$, Basal plasma glucose and insulin levels are comparable in Tg2576 and WT mice ( $n=5-18$ per group). ${ }^{*} p<0.05$, from respective WT by ANOVA for repeated measurements (body weight) or $t$ test for two group comparisons. ${ }^{* *} p<0.01$, from respective WT by $t$ test for two group comparisons.

reports (Kawarabayashi et al., 2001), Tg2576 mice had no visible plaques at 3 months of age, sporadic small plaques at 7 months of age, and widespread, markedly larger amyloid plaques by 14 months of age (Fig. 1). We next evaluated whether Tg2576 mice with elevated levels of APP and A $\beta$ have body weight and metabolic deficits. Compared with WT mice, Tg2576 mice had a mild but significant $10 \%-15 \%$ decrease in body weight until 3 months of age corresponding to a time when there was no amyloid plaque formation (Fig. 2A). The body weight deficits were noted to progressively worsen as $\operatorname{Tg} 2576$ mice aged and the brain amyloid burden increased. The greatest body weight difference was found at $\sim 10$ months of age when brain amyloid levels rapidly increased and amyloid plaques developed (Fig. 2A,B). Because we wanted to investigate the metabolic deficits before amyloid plaque formation, in subsequent studies, we used Tg2576 mice at 3 months of age Next, we assessed the body composition of these mice by MRI to determine whether the difference in body weight was mainly from decreases in fat or lean mass. In 3-month-old Tg2576 mice, total lean mass was slightly reduced, but there was a profound reduction in body adiposity, the total fat mass being less than half of that of WT mice (Fig. 2C-E). The decreased adiposity in 3-month-old Tg2576 mice was associated with markedly reduced plasma leptin levels, but normal glucose and insulin levels (Fig. $2 F-H$ ). Male Tg2576 mice of the same age (3 months) showed body weight deficits (WT: $26.4 \pm 0.8 \mathrm{~g}$; Tg2576:
$23.6 \pm 0.7 \mathrm{~g}, n=12-14$ per group, $p=$ 0.03 ) and low plasma leptin levels (WT: $1.96 \pm 0.34 \mathrm{ng} / \mathrm{ml}$; Tg2576: $0.92 \pm 0.14$ $\mathrm{ng} / \mathrm{ml}, n=7-9$ per group, $p=0.02) \mathrm{sim}$ ilar to those of female mice, suggesting that sex differences did not play a significant role in the observed metabolic deficits. Because both male and female Tg2576 mice had a similar metabolic phenotype associated with a low leptin state, subsequent studies were conducted in female mice. By using females in our studies, we could avoid single-cage housing, needed for male $\mathrm{Tg} 2576$ mice because of their aggressive behavior. Thus, using group-housed females minimizes confounding effects of prolonged social isolation, which can influence body weight, metabolic and neuroendocrine factors (Bartolomucci et al., 2009; Sakakibara et al., 2012).

\section{Transgenic mice overexpressing APP have increased metabolic rate but normal feeding behavior}

To investigate the physiological bases of the decrease in body weight and adiposity in 3-month-old Tg2576 mice, we measured energy input by quantitating food intake and energy expenditure by indirect calorimetry using metabolic cages. Daily food intake did not differ between Tg2576 and WT mice (Fig. 3A). However, Tg2576 mice had increased energy expenditure as measured by $\mathrm{O}_{2}$ consumption throughout both the light and dark cycle (Fig. 3B), particularly at rest (Fig. 3C). Thus, the decrease in body weight and adiposity observed in $\operatorname{Tg} 2576$ mice is associated with increases in energy expenditure rather than alterations in feeding behavior.

\section{Transgenic mice overexpressing APP have abnormal hypothalamic responses to low plasma leptin}

Circulating leptin binds to its receptors on first-order neurons in the arcuate nucleus of the hypothalamus to regulate body weight and adiposity (Gautron and Elmquist, 2011). In the normal response to low adiposity and concomitant low plasma leptin levels, orexigenic arcuate NPY neurons coexpressing agouti-related peptide (AgRP) neurons are activated leading to an increase in transcription of NPY and AgRP genes, whereas the anorexigenic arcuate POMC neurons coexpressing cocaine-amphetaminerelated transcript (CART) are suppressed leading to a decrease in the expression of POMC and CART genes. The coordinated changes in these hypothalamic and other neural circuits lead to increase in food intake and decrease in energy expenditure resulting in restoration of body fat and plasma leptin levels. Because of the abnormal metabolic response to low plasma leptin, we investigated whether Tg2576 mice had an altered hypothalamic response to the low leptin state. To this end, first, we studied whether the expression of leptin receptor in the hypothalamus of Tg2576 mice was altered because of the overexpression of APP. However, no alterations in leptin receptor RNA levels were observed (Fig. 4). Next, we examined the expression levels of the 
A

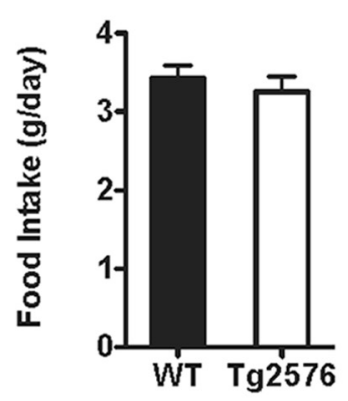

B

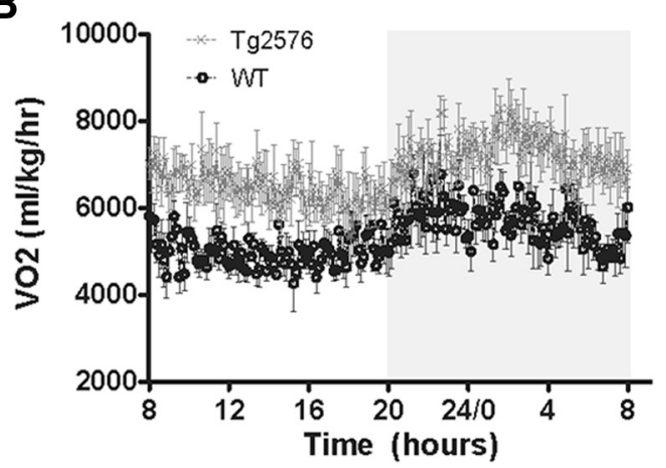

C

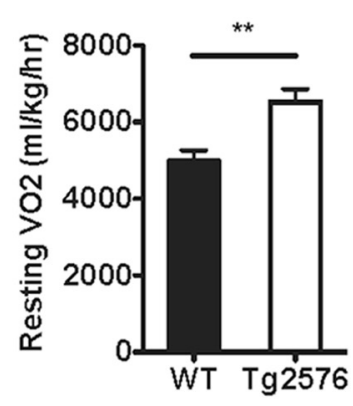

Figure 3. Low body weight in Tg2576 mice is not caused by alterations in feeding behavior but by increased energy expenditure. $A$, Daily food intake in 3-month-0ld Tg2576 mice was the same as WT mice ( $n=6$ or 7 per group). $\boldsymbol{B}$, Energy expenditure was increased in Tg2576 mice throughout the light and dark cycle as measured by increased oxygen consumption (V0 $0_{2}$ in an indirect calorimetry system (0xymax, Columbus Instruments) ( $n=5$ per group). C, Resting metabolic rate, as measured by V $0_{2}$ when the mice were not moving, was significantly increased in Tg 2576 mice ( $n=5$ per group). ${ }^{* *} p<0.01$, from respective WT mice by $t$ test.

A

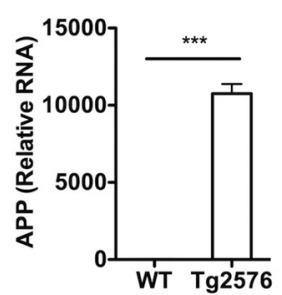

C

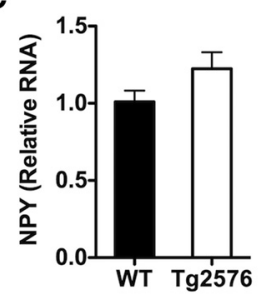

E

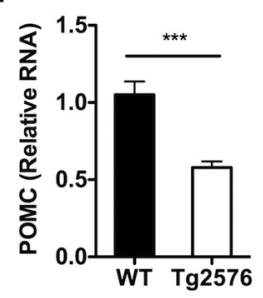

B

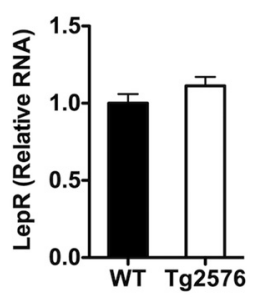

D

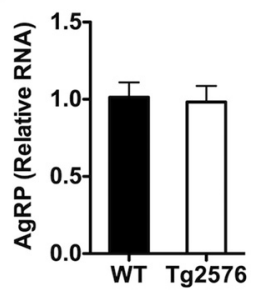

$\mathbf{F}$

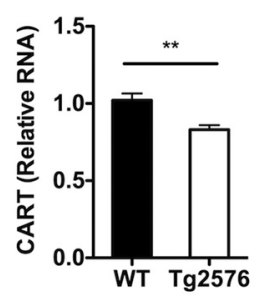

Figure 4. $\operatorname{Tg} 2576$ mice have abnormal hypothalamic responses to the low basal plasma leptin levels. $\boldsymbol{A}$, In the hypothalamus of 3-month-old Tg2576 mice, high levels of human APP $_{\text {swe }}$ RNA are present. $\boldsymbol{B}$, No changes in hypothalamic leptin receptor (LepR) RNA expression in $\operatorname{Tg} 2576$ mice were seen. $\boldsymbol{C}, \boldsymbol{D}$, Unchanged hypothalamic NPY and AgRP RNA levels despite the low plasma leptin levels. $\boldsymbol{E}, \boldsymbol{F}$, An appropriate decrease in hypothalamic POMC and CART RNA levels was observed. All values were normalized with hypoxanthine-guanine phophoribosyltransferase RNA levels and expressed as relative values compared with WT mice. For all, $n=13$ per group. ${ }^{* *} p<0.01$, from respective WT mice by $t$ test. ${ }^{* * *} p<0.001$, from respective WT mice by $t$ test.

leptin-regulated hypothalamic genes in the Tg2576 mice. Despite the low circulating plasma leptin levels, NPY and AgRP RNA levels in Tg2576 mice were not significantly different from WT levels, suggesting an abnormal response to the low leptin in NPY neurons (Fig. 4). Interestingly, POMC and CART levels were appropriately decreased in Tg2576 mice (Fig. 4), suggesting that the dysfunction was selective for NPY neurons.

Transgenic mice overexpressing APP have abnormal hypothalamic responses to fasting

Leptin is thought to be essential for the neuroendocrine response to starvation (Ahima et al., 1996). Therefore, in light of their low leptin levels, we investigated whether Tg2576 mice have an abnormal response to starvation. Mice were fasted for $48 \mathrm{~h}$ to induce a physiological low leptin state. Both fasted Tg2576 and WT mice had similar changes in body weight, blood glucose, and plasma insulin levels (Fig. $5 A, B, D, E$ ). However, although WT mice had appropriately decreased plasma leptin levels after fasting, plasma leptin levels in Tg2576 mice were not significantly changed from the already low basal levels (Fig. 5C). Furthermore, fasted $\operatorname{Tg} 2576$ mice had markedly blunted hypothalamic response in NPY and AgRP RNA levels (Fig. 5G,H), but a normal response in POMC and CART RNA levels (Fig. 5I,J). Thus, whereas fasting induced similar changes in body weight, plasma insulin, and blood glucose in WT and Tg2576 mice, fasted Tg2576 mice continued to have abnormal responses in hypothalamic NPY and AgRP RNA levels.

\section{A $\boldsymbol{\beta}$ suppresses leptin-mediated electrophysiological responses in hypothalamic NPY neurons}

Because the transcriptional responses to low plasma leptin for NPY and AgRP were abnormal in the hypothalamus of Tg2576 mice, we examined whether the electrophysiological responses to leptin were also disrupted in hypothalamic arcuate neurons expressing NPY and AgRP. To selectively identify arcuate NPY neurons that coexpress AgRP, BAC transgenic NPY-hrGFP (NPY-GFP) mice were bred to Tg2576 mice to generate Tg2576 mice with GFP labeling specifically in NPY neurons. Consistent with previous studies (van den Pol et al., 2009), hemizygous NPY-GFP mice with and without the Tg2576 transgene were both found to have strong GFP labeling in arcuate neurons. Using whole-cell current-clamp recording, we first characterized the membrane properties of GFP-expressing arcuate NPY neurons in WT and Tg2576 hypothalamic slices. Compared with WT hypothalamic slices, arcuate NPY neurons in Tg2576 hypothalamic slices have a less negative resting membrane potential (WT: $-73.2 \pm 2.0 \mathrm{mV}$, Tg2576: $-63.1 \pm 4.5 \mathrm{mV}, p=0.0271, n=$ $10-17$ cells per group) and overall decreased spontaneous spike frequency (WT: $8.5 \pm 0.1 \mathrm{~Hz}, \mathrm{Tg} 2576: 2.4 \pm 0.2 \mathrm{~Hz}, p<0.0001$, $n=6$ cells per group). Then, we tested the response of the arcuate NPY neurons to leptin in both WT and Tg2576 brain slices. Leptin has been shown to hyperpolarize and inhibit hypothalamic 
A

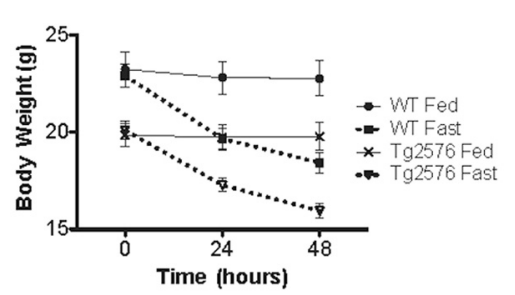

C

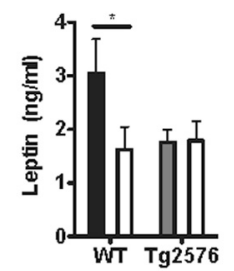

G

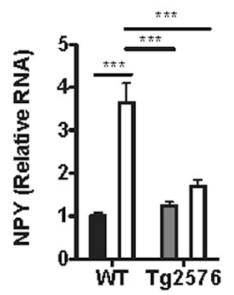

D

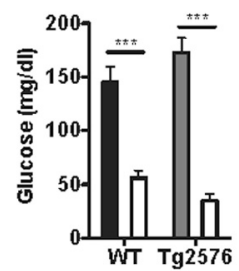

H

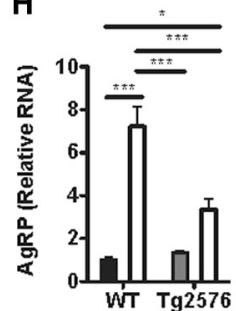

B

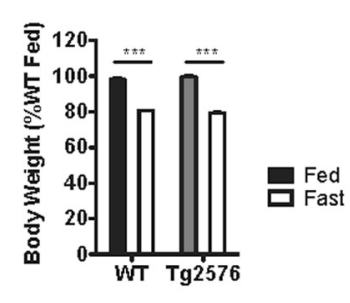

E

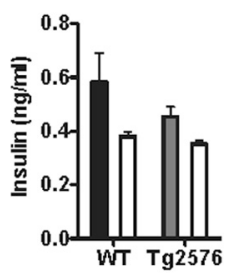

I

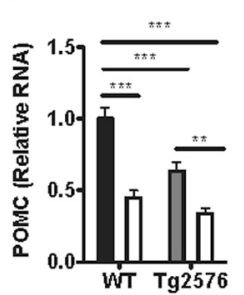

Figure 5. Tg2576 mice have abnormal hypothalamic responses to fasting. $A, B$, Comparable rate of body weight loss after a $48 \mathrm{~h}$ fast was seen in 3-month-old Tg2576 and WT mice. C, The $48 \mathrm{~h}$ fast caused an appropriate lowering of plasma leptin levels in WT mice, but Tg2576 mice had persistently low plasma leptin levels that remained unchanged after the fast. $\boldsymbol{D}, \boldsymbol{E}$, Comparable responses in blood glucose and plasma insulin levels were seen in WT and Tg2576 mice after a $48 \mathrm{~h}$ fast. $\boldsymbol{F}$, Persistently elevated human APP ${ }_{\text {swe }}$ RNA levels in Tg2576 mice were unchanged after a $48 \mathrm{~h}$ fast. G-J, Markedly attenuated hypothalamic NPY (G) and $\operatorname{AgRP}(\boldsymbol{H})$ transcriptional responses, but relatively intact POMC $(\boldsymbol{I})$ and CART $(\boldsymbol{J})$ transcriptional responses were found in $\operatorname{Tg} 2576$ mice after a $48 \mathrm{~h}$ fast. For all, $n=9-12$ per group. ${ }^{*} p<0.05$, from respective WT mice by $t$ test for two group comparison or ANOVA followed by Tukey post hoc test for multigroup comparisons. ${ }^{* *} p<0.01$, from respective WT mice by $t$ test for two group comparison or ANOVA followed by Tukey post hoc test for multigroup comparisons. ${ }^{* *} p<0.001$, from respective WT mice by $t$ test for two group comparison or ANOVA followed by Tukey post hoc test for multigroup comparisons.

NPY neurons (van den Top et al., 2004; Ghamari-Langroudi, 2012). Accordingly, acute application of leptin (100 nM) resulted in hyperpolarization of arcuate NPY neurons in WT hypothalamic slices (Fig. 6A,B). However, this effect of leptin was absent in arcuate NPY neurons in Tg2576 hypothalamic slices (Fig. $6 \mathrm{~A}, \mathrm{~B})$. We also tested ghrelin (100 $\mathrm{nm})$, an orexigenic peptide that depolarizes and activates arcuate NPY neurons (Cowley et al., 2003; Kohno et al., 2003; Ghamari-Langroudi, 2012). Consistent with previous reports (Cowley et al., 2003), ghrelin induced depolarization and transiently increased spike frequency in arcuate NPY neurons in WT hypothalamic slices (Fig. 6C,D), a response markedly attenuated in Tg2576 slices (Fig. 6C,D). Thus, arcuate NPY neurons in Tg2576 mice have an abnormal response to both leptin and ghrelin.

To determine whether $\mathrm{A} \beta$ could be responsible for the neurophysiological alterations in arcuate NPY neurons observed in Tg2576 hypothalamic slices, we examined whether exogenous $\mathrm{A} \beta$ could reproduce such dysfunction in WT hypothalamic slices. Because $A \beta$ oligomers may be involved in the neuronal dysfunction seen in AD (Iversen et al., 1995; Querfurth and LaFerla, 2010), we next tested whether oligomeric $A \beta 1-42$ could inhibit the response to leptin in arcuate NPY neurons. Application of oligomeric A $\beta 1-42(10-100 \mathrm{~nm}, n=7-12$ cells per group) in WT hypothalamic slices depolarized arcuate NPY neurons in a dose-dependent manner $\left(\mathrm{EC}_{50}=29.7 \mathrm{nM}\right)($ Fig. $7 A, B)$.
$\mathbf{F}$

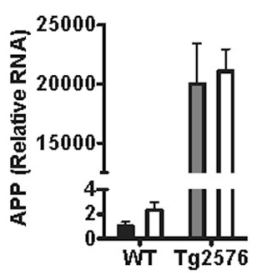

J

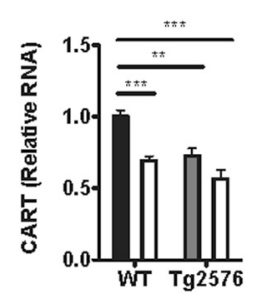

A reduction in the amplitude of the action potentials was also noticed, but the mechanisms remain unclear. Oligomeric $\mathrm{A} \beta 1-42$ blocked the responses to ghrelin $(100 \mathrm{~nm})$ in arcuate NPY neurons dosedependently (Fig. $7 D, F, G$; $\mathrm{IC}_{50}=10.2$ nM, $n=4-7$ cells per group). Furthermore, oligomeric $A \beta 1-42$ also inhibited the leptin-mediated hyperpolarization of arcuate NY neurons (Fig. 7C,E). Thus, the overall effects of $A \beta 1-42$ on resting membrane potential and the electrophysiological responses to leptin and ghrelin in hypothalamic arcuate NPY neurons were similar to those seen in Tg2576 brain slices.

\section{Increased amyloid burden in the brain aggravates leptin-associated metabolic dysfunction}

Our studies have thus far focused on young Tg2576 mice before amyloid plaque formation. However, in $\mathrm{AD}$ patients, the weight loss progressively worsens and correlates with disease severity and increased mortality (White et al., 1998). Therefore, we analyzed the metabolic deficits of Tg2576 mice at 14 months of age when there are prominent amyloid plaques. By 14 months of age, Tg2576 mice had an even more profound body weight deficit compared with preamyloid plaque 3-month-old $\operatorname{Tg} 2576$ mice and continued to have low adiposity (Figs. $1 A, B$ and $8 A, B)$. Furthermore, this pronounced weight deficit and decreased adiposity in the 14-month-old Tg2576 mice correlated with significantly lower relative plasma leptin levels $(13.4 \pm 3.2 \%$ of WT levels at 14 months of age compared with $52.5 \pm 7.1 \%$ of WT levels at 3 months of age, $n=4-15$ per group, $p=0.01$ ) (Fig. $8 C$ ). Of note, in contrast to 3 -month-old mice, significantly lower plasma insulin levels were seen in 14-month-old Tg2576 mice (Fig. 8D). Furthermore, unlike younger 3-month-old Tg2576 mice, 14-month-old Tg2576 mice had significantly decreased food intake (WT: $3.59 \pm 0.09$ $\mathrm{g} / \mathrm{d}, \mathrm{Tg} 2576: 3.03 \pm 0.08 \mathrm{~g} / \mathrm{d}, p=0.01, n=6$ per group), which likely contributed to the worsening body weight disparity between aged Tg2576 and WT mice. Thus, in Tg2576 mice, as in $\mathrm{AD}$ patients, the body weight and metabolic alterations associated with the low leptin state are seen early in the disease process and worsen as the brain amyloid burden increases.

\section{Discussion}

We set out to elucidate the pathogenic mechanisms leading to the accelerated early weight loss seen in preclinical AD (Johnson et al., 2006). We hypothesized that the weight loss was the result of excess $\mathrm{A} \beta$ causing hypothalamic leptin signaling dysfunction. We found that $\mathrm{Tg} 2576$ mice have early body weight deficits characterized by markedly decreased adiposity and abnormally low plasma leptin levels occurring before amyloid plaque formation and abnormalities in feeding behavior. Importantly, Tg2576 mice allowed us to investigate the molecular and cellular mechanisms underlying the weight deficits resulting from increased 

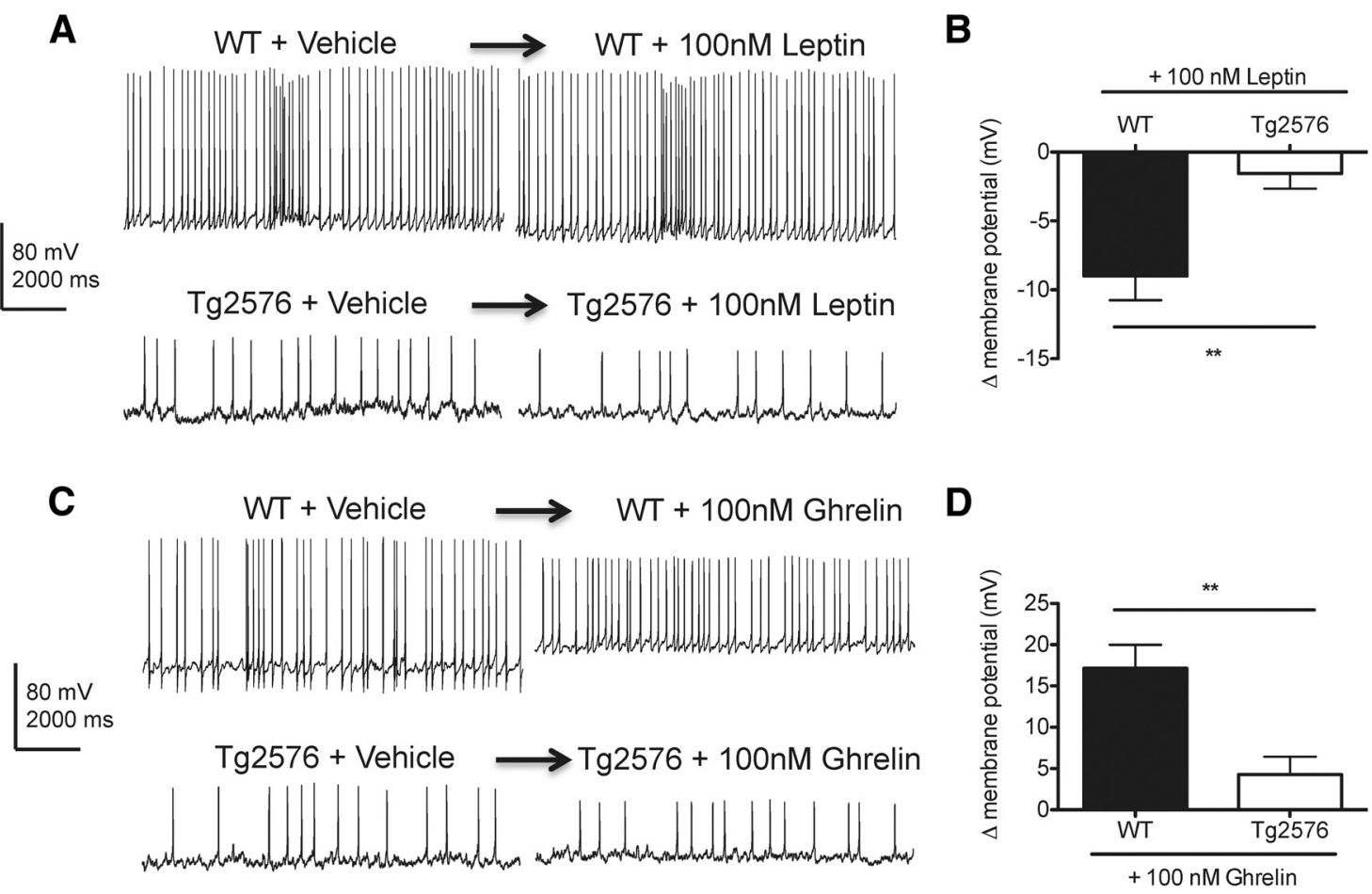

Figure 6. Leptin-mediated hyperpolarization of hypothalamic arcuate NPY neurons is absent in Tg2576 mice. $A$, Leptin (100 nm) hyperpolarized arcuate NPY neurons in WT but not in

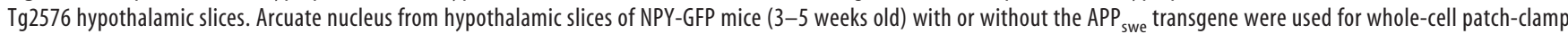
recordings. Representative traces are shown $5 \mathrm{~min}$ after leptin application. $\boldsymbol{B}$, Changes in membrane potentials determined from the recordings of arcuate NPY neurons after application of leptin (100 nm) in WT and Tg2576 hypothalamic slices. $n=8-10$ cells recorded. Spontaneous spike frequency in arcuate NPY neurons after acute application of leptin remained unchanged in both WT (WT + Vehicle: $8.40 .3 \mathrm{~Hz}$, WT + leptin: $7.9 \pm 0.6 \mathrm{~Hz}, p=0.52, n=3$ cells per group) and Tg2576 hypothalamic slices (Tg2576 + Vehicle: $1.9 \pm 0.1 \mathrm{~Hz}$, Tg2576 + leptin: $2.6 \pm 0.3 \mathrm{~Hz}, p=0.1015, n=3$ cells per group). C, Ghrelin (100 nM) strongly depolarized arcuate NPY neurons in WT but not in Tg2576 hypothalamic slices. Representative traces are shown $5 \mathrm{~min}$ after ghrelin application. The increase in resting potential is associated with a reduction in the amplitude of the action potentials. $\boldsymbol{D}$, Changes in membrane potentials determined from the recordings of arcuate NPY neurons after application of ghrelin (100 nM) in WT and Tg2576 hypothalamic slices. $n=7$ or 8 cells recorded. Ghrelin $(100 \mathrm{~nm})$ transiently increased spontaneous spike frequencies in the first $15 \mathrm{~s}$ after acute application of ghrelin (WT + Vehicle: $6.1 \pm 0.8 \mathrm{~Hz}, \mathrm{WT}+\mathrm{ghrelin:} 14 \pm 0.6 \mathrm{~Hz}, p<$ $0.05, n=5$ cells each), whereas no effects on spike frequencies were seen in Tg2576 hypothalamic slices (Tg2576 + Vehicle: $2.8 \pm 0.3 \mathrm{~Hz}, \operatorname{Tg} 2576+$ ghrelin: $2.5 \pm 0.1 \mathrm{~Hz}, p=0.373$, $n=6$ cells each). ${ }^{* *} p<0.01$, from WT cells by $t$ test.

amyloid burden before amyloid plaque formation. Our studies suggest that the low leptin state arises from excess $A \beta$ causing dysfunction in arcuate NPY neurons. This was supported by two findings: (1) in vivo studies in Tg2576 mice showing abnormal hypothalamic NPY and AgRP transcriptional responses in basal and fasting conditions; and (2) ex vivo electrophysiology studies showing abnormal responses to leptin and grehlin in arcuate NPY neurons from Tg2576 hypothalamic slices with endogenous $\mathrm{A} \beta$ and WT hypothalamic slices exposed to exogenous $\mathrm{A} \beta 1-42$. Finally, consistent with the progressive nature of $\mathrm{AD}$, the body weight and associated metabolic deficits worsened as the amyloid burden increased. Collectively, these observations provide novel evidence that APP overexpression and/or excess $\mathrm{A} \beta$ can cause hypothalamic dysfunction in leptin-responsive neurons that could contribute to body weight loss and a pathologically low leptin state.

\section{Leptin signaling in AD}

Low levels of plasma leptin have been recently linked with AD. Epidemiological studies have demonstrated that low plasma leptin levels correlate with increased risk of developing AD and agerelated cognitive deficits (Power et al., 2001; Holden et al., 2009; Lieb et al., 2009). Low plasma leptin levels were also found in humans diagnosed with mild cognitive impairment (Johnston et al., 2014). Therefore, low plasma leptin levels may serve as an early biomarker for $\mathrm{AD}$. In this context, our studies suggest that the low leptin state seen early in $\mathrm{AD}$ reflects hypothalamic dysfunction caused by $\mathrm{A} \beta$. We propose that, early in $\mathrm{AD}$ pathogenesis, $A \beta$ has the potential of inhibiting key hypothalamic neurons necessary for leptin signaling to maintain proper regulation of body weight (Fig. 9). In this model, excess $\mathrm{A} \beta$ early in the disease disrupts the efferent arm in the central regulation of body weight to cause low body weight and a pathologically low leptin state.

Although our findings suggest that overexpression of APP leads to a low leptin state, it does not directly link leptin to cognitive dysfunction in $\mathrm{AD}$. However, several lines of evidence suggest that leptin may serve important roles in cognition, memory, and neuroprotection from the toxic effects of $\mathrm{A} \beta$. Genetically leptin-deficient mice have, in addition to the obesity and metabolic deficits, lower brain weight, cognitive deficiency, and evidence of hippocampal synaptic dysfunction (Ahima et al., 1999; Harvey, 2013). Administration of leptin to these leptin-deficient mice improves not only the obesity but also cognitive function and synaptic plasticity and function (Harvey, 2013). Similarly, a child with congenital leptin deficiency had abnormal neurocognitive development that was substantially improved after leptin replacement therapy (Paz-Filho et al., 2008). Furthermore, in vitro studies have shown that leptin can enhance long-term potentiation and also protects against $\mathrm{A} \beta$ toxicity in hippocampal neurons (Doherty et al., 2013; Harvey, 2013), whereas in vivo studies demonstrate that exogenous leptin can reverse amyloid- 
A

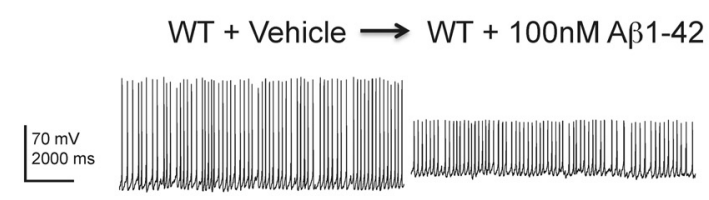

C

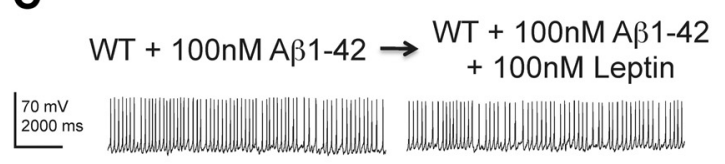

E

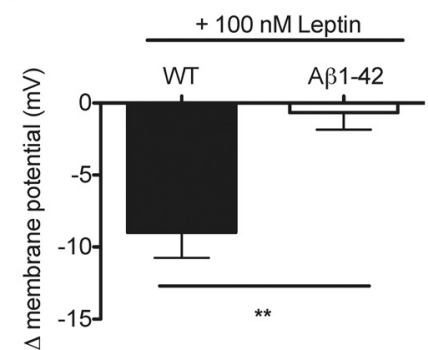

F

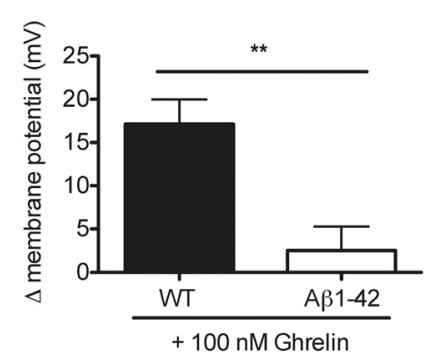

B

D

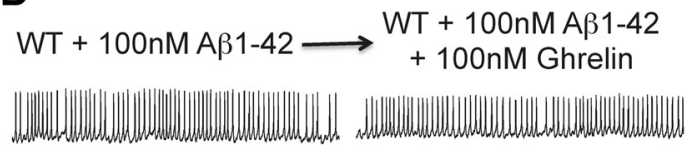

G

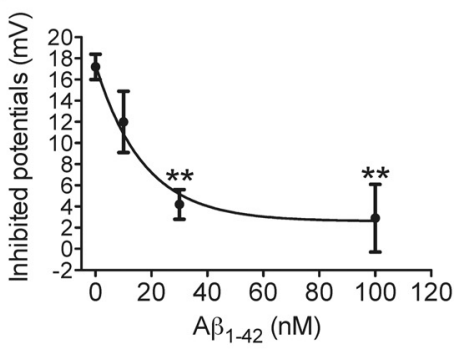

Figure 7. Leptin-mediated hyperpolarization of hypothalamic arcuate NPY neurons is absent after application of oligomeric $A \beta 1-42 . A$, Application of oligomeric A 1 - 42 (100 nм) to WT hypothalamic slices depolarized arcuate NPY neurons. The increase in resting potential is associated with a reduction in the amplitude of the action potentials. Brain slices containing the hypothalamic arcuate nucleus from NPY-GFP mice (3-5 weeks old) were used for whole-cell patch-clamp recordings. The recordings show the duration before and after oligomeric $A \beta 1-42$ application. $\boldsymbol{B}$, Oligomeric A $\beta 1-42$ (10,30, and $100 \mathrm{~nm})$ depolarized arcuate NPY neurons in a dose-dependent fashion ( $n=7-25$ cells recorded). C, D, Exposure to oligomeric A $\beta 1-42$ (100 nM) inhibited the electrophysiological responses to both leptin $(100 \mathrm{~nm})(\boldsymbol{C})$ and ghrelin $(100 \mathrm{~nm})(\boldsymbol{D})$ in arcuate NPY neurons. Representative traces are shown. $\boldsymbol{E}-\boldsymbol{G}$, Changes in membrane potentials determined from the recordings of arcuate NPY neurons after leptin $(100 \mathrm{nM})(\boldsymbol{E})$ and ghrelin $(100 \mathrm{nM})(\boldsymbol{F}, \boldsymbol{G})$ application to WT hypothalamic slices treated with oligomeric $A \beta 1-42(100 \mathrm{~nm}) . n=$ $4-8$ cells recorded. Although membrane potentials in arcuate NPY neurons were readily affected by oligomeric $A \beta 1-42$, spontaneous spike frequency remained unchanged under all conditions tested (WT + Vehicle: $8.4 \pm 0.5 \mathrm{~Hz}$, WT $+\mathrm{A} \beta 1-42: 7.6 \pm 0.2 \mathrm{~Hz}$, WT $+\mathrm{A} \beta 1-42+$ Leptin: $8.1 \pm 0.3 \mathrm{~Hz}$, WT $+\mathrm{A} \beta 1-42+$ Ghrelin: $7.9 \pm 0.2 \mathrm{~Hz}, p>0.05$ for all; $n=3-5$ cells per group). ${ }^{* *} p<0.01$, from WT cells by $t$ test.

related pathology and cognitive decline in transgenic mice models overexpressing APP (Greco et al., 2010). These studies collectively indicate that leptin may regulate neurocognitive function and support a "protective role" of leptin against $\mathrm{AD}$; however, additional studies are needed to confirm and support these findings.

\section{Hypothalamic dysfunction in $\mathrm{AD}$}

Although the emphasis in $\mathrm{AD}$ is often placed on the hippocampus and other brain structures directly involved in cognition and memory, the hypothalamus is clearly involved in AD. Significant atrophy has been identified in the hypothalamus of $\mathrm{AD}$ subjects by MR volumetric analysis (Callen et al., 2001). Also, pathological changes consistent with $\mathrm{AD}$, including neurofibrillary tangles and amyloid plaques, have been found in the hypothalamus of postmortem AD brains (McDuff and Sumi, 1985; Saper and German, 1987; Braak and Braak, 1991). Furthermore, deep brain stimulation in the hypothalamus, introduced as a treatment for obesity, improved memory in AD subjects (Laxton et al., 2010). Therefore, understanding how the hypothalamus is affected early in $\mathrm{AD}$ may offer new insights into the metabolic and cognitive dysfunction associated with $\mathrm{AD}$.

\section{NPY dysfunction in AD}

We focused our studies on the first-order leptin-responsive arcuate NPY neurons coexpressing AgRP, an essential site of action for leptin to regulate body weight (Gautron and Elmquist, 2011).
To our knowledge, there have been no reports linking these arcuate neurons or AgRP to AD. Interestingly, there have been sporadic reports associating forebrain NPY to AD. Plasma and CSF NPY levels as well as NPY immunoreactivity in cerebral cortex have all been found to be lower in AD (Beal et al., 1986; Alom et al., 1990; Koide et al., 1995). Furthermore, in a mouse model overexpressing APP, abnormalities in hippocampal NPY network function were associated with the increased seizure activity seen in this mouse model and in AD patients (Palop et al., 2007). In addition, central administration of NPY improved learning and memory behavior in a colchicine-induced rat model of AD (Rangani et al., 2012), whereas proteolytic fragments of NPY derived from neprilysin processing were found to be neuroprotective in a mouse model overexpressing APP (Rose et al., 2009). Our findings that $A \beta$ profoundly downregulates arcuate NPY signaling are overall consistent with these clinical and animal studies.

We showed, for the first time, that $\mathrm{A} \beta$ can affect the electrophysiological properties of hypothalamic neurons at low concentrations. This finding was demonstrated in arcuate NPY neurons from Tg2576 and A $\beta 1-42$ treated WT hypothalamic slices. Although we believe that oligomeric $\mathrm{A} \beta 1-42$ is the probable pathogenic agent acting on the hypothalamus, we cannot exclude that APP and/or other proteolytic fragments of APP could also contribute to hypothalamic dysfunction (see Limitations of the mouse model). Furthermore, because the neurophysiological responses to both leptin and ghrelin were affected, the hypotha- 
lamic dysfunction caused by $\mathrm{A} \beta$ is not specific to the leptin pathway. Additional studies are needed to further investigate the possible pathophysiological mechanisms underlying the hypothalamic dysfunction caused by $\mathrm{A} \beta$. In particular, the effects of $A \beta$ on the ion channels responsible for the alterations in leptin and ghrelin-mediated electrophysiological responses in NPY neurons need to be investigated. Future studies will also need to determine the exact nature of the involvement of NPY and/or AgRP signaling in $\mathrm{AD}$ and whether increasing NPY and/or AgRP signaling would be therapeutically beneficial in AD. Finally, the role of other leptin-responsive hypothalamic and extrahypothalamic neurons needs to be elucidated.

\section{Limitations of the mouse model}

Mouse models leading to $\mathrm{A} \beta$ accumulation have limitations concerning how accurately they recapitulate AD (Chin, 2011). In Tg2576 mice, overexpression of APP itself or APP fragments other than $\mathrm{A} \beta$ may contribute to the phenotype. APP knock-in mice or transgenic mice that generate only $\mathrm{A} \beta 1-42$ will help address this problem (McGowan et al., 2005; Saito et al., 2014). In addition, $A \beta$ levels are increased not only in brain but also in plasma (Kawarabayashi et al., 2001). Therefore, circulating A $\beta$ may play a role in the metabolic deficits seen in $\mathrm{Tg} 2576$ mice. The contribution of plasma $A \beta$ to $\mathrm{AD}$ remains controversial, but plasma $\mathrm{A} \beta$ levels are elevated at least in early phases of $\mathrm{AD}$ and in carriers of familial AD mutations (Schupf et al., 2008; Bateman et al., 2012). A recent study found that WT mice receiving chronic peripheral administration of exogenous $A \beta 1-42$ in concentrations that elevated plasma $A \beta 1-42$ levels similar to those in Tg2576 mice induced hepatic insulin resistance, but there was no alteration in body weight in these mice (Zhang et al., 2013). Therefore, it is unlikely that our findings in $\mathrm{Tg} 2576$ mice are entirely attributable to peripheral effects. However, future studies will have to address this issue in mouse models with elevated $\mathrm{A} \beta$ levels restricted to the brain.

\section{Conclusion}

In conclusion, we have demonstrated that Tg2576 mice have decreased body weight and adiposity, leading to a state of pathologically low plasma leptin at an age before amyloid plaque formation or alterations in feeding behavior. This low leptin state was associated with hypothalamic dys-
A

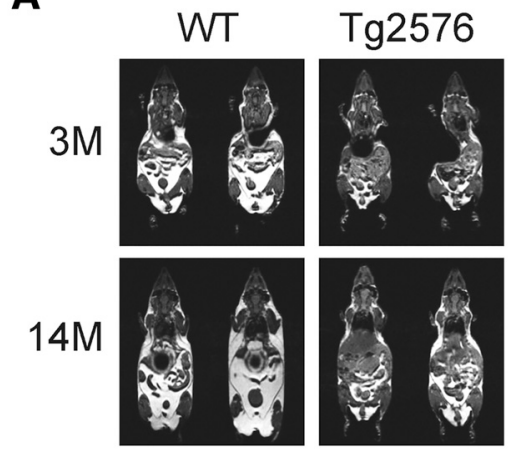

C

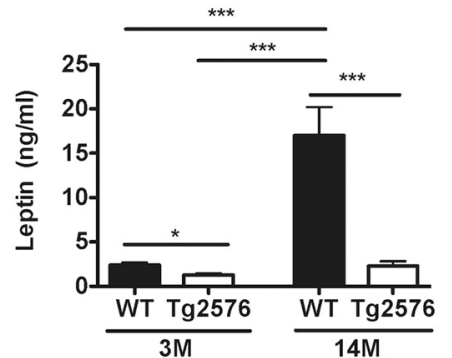

B

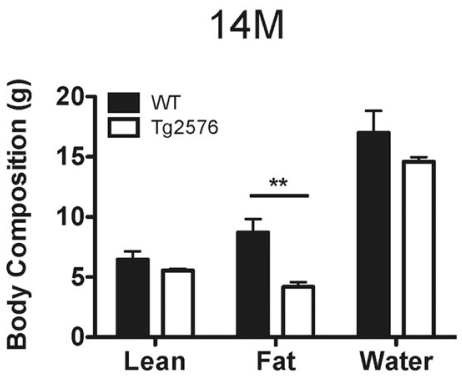

D

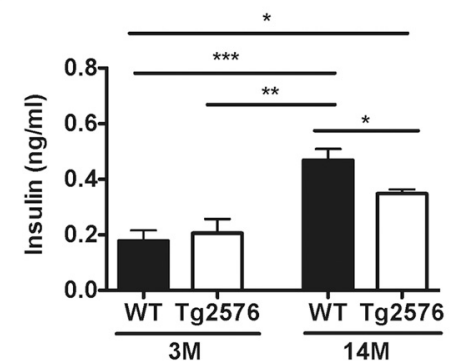

Figure 8. Aged Tg2576 mice with prominent amyloid plaques have worsening leptin-associated metabolic deficits compared with young Tg2576 mice with no amyloid plaques. A, Representative T1-weighted MR images showing an increase in adipose tissue (bright, hyperintense signal) as WT mice age from 3 months (3M) to 14 months (14M), whereas aged Tg2576 mice continue to have markedly lower overall body adiposity. B. The 14-month-old Tg2576 mice continue to have low adiposity compared with similarly aged WT mice as demonstrated by quantitative body composition analysis by MR spectroscopy ( $n=6$ per group). $C$, Increasing relative disparity in plasma leptin levels in 14-month-old (14M) Tg2576 mice to 14-month-old WT mice compared with plasma leptin levels in 3-month-old mice. $\boldsymbol{D}$, The 14-month-old Tg2576 mice have significantly lower plasma insulin levels compared with 14-month-old WT mice. No significant difference in insulin levels was seen at 3 months of age. For all, $n=4-15$ per group. ${ }^{*} p<0.05$, from respective WT or group comparison by $t$ test for two group comparisons or ANOVA followed by Tukey posthoc test for multigroup comparisons. ${ }^{* *} p<0.01$, from respective WT or group comparison by $t$ test for two group comparisons or ANOVA followed by Tukey post hoc test for multigroup comparisons. ${ }^{* * *} p<0.001$, from respective WT or group comparison by $t$ test for two group comparisons or ANOVA followed by Tukey post hoc test for multigroup comparisons.

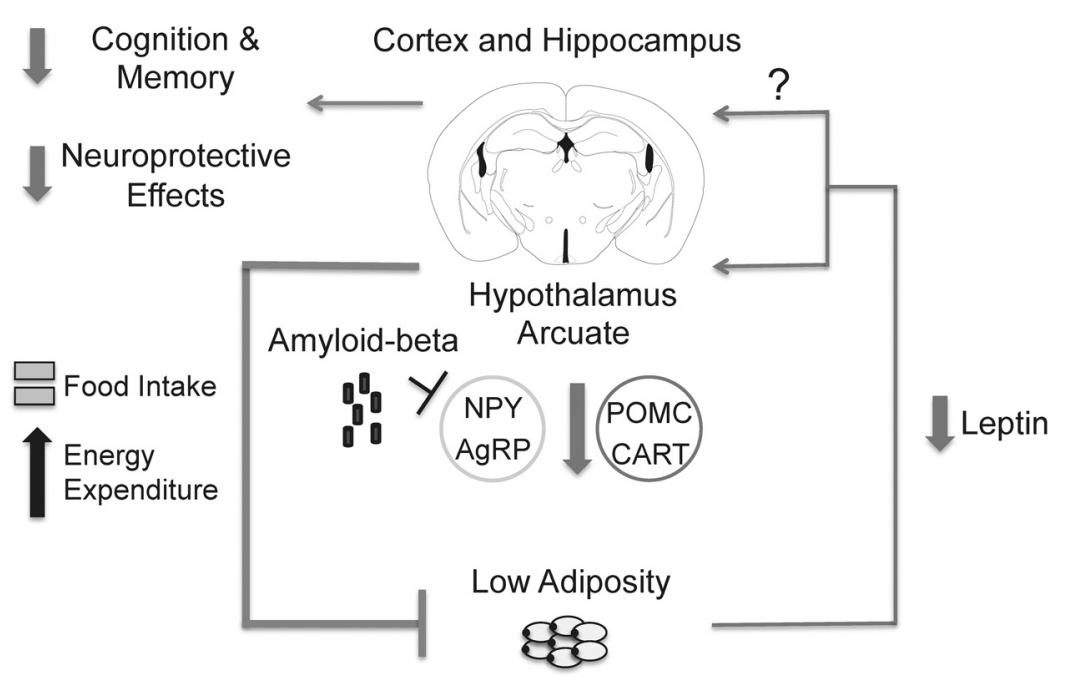

Fat Mass

Figure 9. Schematic demonstrating a proposed pathophysiological mechanism for the early weight loss and low plasma leptin levels in young preamyloid plaque Tg2576 mice. In this model, excess A $\beta$ causes dysfunction in hypothalamic arcuate NPY neurons and possibly other leptin-responsive neurons to disrupt the efferent signal regulating body weight. This ultimately results in decreased adiposity and a state of pathologically low levels of plasma leptin, which may decrease leptin's potential procognitive and neuroprotective effects against $A \beta$ toxicity in the cortex and hippocampus. The mouse brain figure was adapted from a mouse brain atlas (Paxinos and Franklin, 2004). 
function in arcuate NPY neurons as demonstrated by abnormal transcriptional responses to the low plasma leptin levels in basal and fasting conditions, as well as in abnormal electrophysiological responses to leptin and ghrelin. We also established that the body weight deficits worsened as the amyloid burden increased in Tg2576 mice. These novel findings provide evidence that the weight loss associated with AD could be an intrinsic feature of the disease caused by $\mathrm{A} \beta$-related dysfunction of arcuate NPY neurons. The data raise the possibility that restoring leptin signaling in arcuate NPY neurons and other brain regions could lead to novel therapies for AD. Furthermore, plasma leptin and related molecules could also be biomarkers for early $\mathrm{AD}$, further enhancing the ability to diagnose $\mathrm{AD}$ during the preclinical stage and enabling earlier therapeutic options.

\section{References}

Ahima RS, Prabakaran D, Mantzoros C, Qu D, Lowell B, Maratos-Flier E, Flier JS (1996) Role of leptin in the neuroendocrine response to fasting. Nature 382:250-252. CrossRef Medline

Ahima RS, Bjorbaek C, Osei S, Flier JS (1999) Regulation of neuronal and glial proteins by leptin: implications for brain development. Endocrinology 140:2755-2762. CrossRef Medline

Alom JA, Galard R, Catalan R, Castellanos JM, Schwartz S, Tolosa E (1990) Cerebrospinal fluid neuropeptide Y in Alzheimer's disease. Eur Neurol 30:207-210. CrossRef Medline

Barrett-Connor E, Edelstein SL, Corey-Bloom J, Wiederholt WC (1996) Weight loss precedes dementia in community-dwelling older adults. J Am Geriatr Soc 44:1147-1152. Medline

Bartolomucci A, Cabassi A, Govoni P, Ceresini G, Cero C, Berra D, Dadomo H, Franceschini P, Dell'Omo G, Parmigiani S, Palanza P (2009) Metabolic consequences and vulnerability to diet-induced obesity in male mice under chronic social stress. PLoS One 4:e4331. CrossRef Medline

Bateman RJ, Xiong C, Benzinger TL, Fagan AM, Goate A, Fox NC, Marcus DS, Cairns NJ, Xie X, Blazey TM, Holtzman DM, Santacruz A, Buckles V, Oliver A, Moulder K, Aisen PS, Ghetti B, Klunk WE, McDade E, Martins $\mathrm{RN}$, et al. (2012) Clinical and biomarker changes in dominantly inherited Alzheimer's disease. N Engl J Med 367:795-804. CrossRef Medline

Beal MF, Mazurek MF, Chattha GK, Svendsen CN, Bird ED, Martin JB (1986) Neuropeptide Y immunoreactivity is reduced in cerebral cortex in Alzheimer's disease. Ann Neurol 20:282-288. CrossRef Medline

Braak H, Braak E (1991) Neuropathological stageing of Alzheimer-related changes. Acta Neuropathol 82:239-259. CrossRef Medline

Buchman AS, Wilson RS, Bienias JL, Shah RC, Evans DA, Bennett DA (2005) Change in body mass index and risk of incident Alzheimer disease. Neurology 65:892-897. CrossRef Medline

Callen DJ, Black SE, Gao F, Caldwell CB, Szalai JP (2001) Beyond the hippocampus: MRI volumetry confirms widespread limbic atrophy in AD. Neurology 57:1669-1674. CrossRef Medline

Chin J (2011) Selecting a mouse model of Alzheimer's disease. Methods Mol Biol 670:169-189. CrossRef Medline

Cowley MA, Smith RG, Diano S, Tschöp M, Pronchuk N, Grove KL, Strasburger CJ, Bidlingmaier M, Esterman M, Heiman ML, Garcia-Segura LM, Nillni EA, Mendez P, Low MJ, Sotonyi P, Friedman JM, Liu H, Pinto S, Colmers WF, Cone RD, et al. (2003) The distribution and mechanism of action of ghrelin in the CNS demonstrates a novel hypothalamic circuit regulating energy homeostasis. Neuron 37:649-661. CrossRef Medline

Doherty GH, Beccano-Kelly D, Yan SD, Gunn-Moore FJ, Harvey J (2013) Leptin prevents hippocampal synaptic disruption and neuronal cell death induced by amyloid $\beta$. Neurobiol Aging 34:226-237. CrossRef Medline

Gautron L, Elmquist JK (2011) Sixteen years and counting: an update on leptin in energy balance. J Clin Invest 121:2087-2093. CrossRef Medline

Ghamari-Langroudi M (2012) Electrophysiological analysis of circuits controlling energy homeostasis. Mol Neurobiol 45:258-278. CrossRef Medline

Greco SJ, Bryan KJ, Sarkar S, Zhu X, Smith MA, Ashford JW, Johnston JM, Tezapsidis N, Casadesus G (2010) Leptin reduces pathology and improves memory in a transgenic mouse model of Alzheimer's disease. J Alzheimers Dis 19:1155-1167. CrossRef Medline

Harvey J (2013) Leptin regulation of neuronal morphology and hippocampal synaptic function. Front Synaptic Neurosci 5:3. CrossRef Medline
Holden KF, Lindquist K, Tylavsky FA, Rosano C, Harris TB, Yaffe K; Health ABC study (2009) Serum leptin level and cognition in the elderly: findings from the Health ABC Study. Neurobiol Aging 30:1483-1489. CrossRef Medline

Hsiao KK, Borchelt DR, Olson K, Johannsdottir R, Kitt C, Yunis W, Xu S, Eckman C, Younkin S, Price D (1995) Age-related CNS disorder and early death in transgenic FVB/N mice overexpressing Alzheimer amyloid precursor proteins. Neuron 15:1203-1218. CrossRef Medline

Hsiao K, Chapman P, Nilsen S, Eckman C, Harigaya Y, Younkin S, Yang F, Cole G (1996) Correlative memory deficits, Abeta elevation, and amyloid plaques in transgenic mice. Science 274:99-102. CrossRef Medline

Ishii M, Fei H, Friedman JM (2003) Targeted disruption of GPR7, the endogenous receptor for neuropeptides $\mathrm{B}$ and $\mathrm{W}$, leads to metabolic defects and adult-onset obesity. Proc Natl Acad Sci U S A 100:10540-10545. CrossRef Medline

Iversen LL, Mortishire-Smith RJ, Pollack SJ, Shearman MS (1995) The toxicity in vitro of beta-amyloid protein. Biochem J 311:1-16. Medline

Jackman K, Kahles T, Lane D, Garcia-Bonilla L, Abe T, Capone C, Hochrainer K, Voss H, Zhou P, Ding A, Anrather J, Iadecola C (2013) Progranulin deficiency promotes post-ischemic blood-brainbarrier disruption. J Neurosci 33:19579-19589. CrossRef Medline

Johnson DK, Wilkins CH, Morris JC (2006) Accelerated weight loss may precede diagnosis in Alzheimer disease. Arch Neurol 63:1312-1317. CrossRef Medline

Johnston JM, Hu WT, Fardo DW, Greco SJ, Perry G, Montine TJ, Trojanowski JQ, Shaw LM, Ashford JW, Tezapsidis N; Alzheimer's Disease Neuroimaging Initiative (2014) Low plasma leptin in mild cognitively impaired/Alzheimer's disease ADNI1 subjects: gender differences and diagnostic and therapeutic potential. Curr Alzheimer Res 11:165-174. CrossRef Medline

Kawarabayashi T, Younkin LH, Saido TC, Shoji M, Ashe KH, Younkin SG (2001) Age-dependent changes in brain, CSF, and plasma amyloid (beta) protein in the Tg2576 transgenic mouse model of Alzheimer's disease. J Neurosci 21:372-381. Medline

Kohno D, Gao HZ, Muroya S, Kikuyama S, Yada T (2003) Ghrelin directly interacts with neuropeptide-Y-containing neurons in the rat arcuate nucleus: $\mathrm{Ca}^{2+}$ signaling via protein kinase $\mathrm{A}$ and $\mathrm{N}$-type channel-dependent mechanisms and cross-talk with leptin and orexin. Diabetes 52:948-956. CrossRef Medline

Koide S, Onishi H, Hashimoto H, Kai T, Yamagami S (1995) Plasma neuropeptide $\mathrm{Y}$ is reduced in patients with Alzheimer's disease. Neurosci Lett 198:149-151. CrossRef Medline

Laxton AW, Tang-Wai DF, McAndrews MP, Zumsteg D, Wennberg R, Keren R, Wherrett J, Naglie G, Hamani C, Smith GS, Lozano AM (2010) A phase I trial of deep brain stimulation of memory circuits in Alzheimer's disease. Ann Neurol 68:521-534. CrossRef Medline

Lieb W, Beiser AS, Vasan RS, Tan ZS, Au R, Harris TB, Roubenoff R, Auerbach S, DeCarli C, Wolf PA, Seshadri S (2009) Association of plasma leptin levels with incident Alzheimer disease and MRI measures of brain aging. JAMA 302:2565-2572. CrossRef Medline

Livak KJ, Schmittgen TD (2001) Analysis of relative gene expression data using real-time quantitative PCR and the 2(-Delta Delta C(T)) Method. Methods 25:402-408. CrossRef Medline

McDuff T, Sumi SM (1985) Subcortical degeneration in Alzheimer's disease. Neurology 35:123-126. CrossRef Medline

McGowan E, Pickford F, Kim J, Onstead L, Eriksen J, Yu C, Skipper L, Murphy MP, Beard J, Das P, Jansen K, Delucia M, Lin WL, Dolios G, Wang R, Eckman CB, Dickson DW, Hutton M, Hardy J, Golde T (2005) Abeta42 is essential for parenchymal and vascular amyloid deposition in mice. Neuron 47:191-199. CrossRef Medline

Mystkowski P, Shankland E, Schreyer SA, LeBoeuf RC, Schwartz RS, Cummings DE, Kushmerick M, Schwartz MW (2000) Validation of wholebody magnetic resonance spectroscopy as a tool to assess murine body composition. Int J Obes Relat Metab Disord 24:719-724. CrossRef Medline

Palop JJ, Chin J, Roberson ED, Wang J, Thwin MT, Bien-Ly N, Yoo J, Ho KO, Yu GQ, Kreitzer A, Finkbeiner S, Noebels JL, Mucke L (2007) Aberrant excitatory neuronal activity and compensatory remodeling of inhibitory hippocampal circuits in mouse models of Alzheimer's disease. Neuron 55:697-711. CrossRef Medline

Park L, Zhou P, Pitstick R, Capone C, Anrather J, Norris EH, Younkin L, Younkin S, Carlson G, McEwen BS, Iadecola C (2008) Nox2-derived 
radicals contribute to neurovascular and behavioral dysfunction in mice overexpressing the amyloid precursor protein. Proc Natl Acad Sci U S A 105:1347-1352. CrossRef Medline

Paxinos G, Franklin KBJ (2001) The mouse brain in stereotaxic coordinates, Ed 2. San Diego: Academic.

Paz-Filho GJ, Babikian T, Asarnow R, Delibasi T, Esposito K, Erol HK, Wong ML, Licinio J (2008) Leptin replacement improves cognitive development. PLoS One 3:e3098. CrossRef Medline

Power DA, Noel J, Collins R, O’Neill D (2001) Circulating leptin levels and weight loss in Alzheimer's disease patients. Dement Geriatr Cogn Disord 12:167-170. CrossRef Medline

Querfurth HW, LaFerla FM (2010) Alzheimer's disease. N Engl J Med 362: 329-344. CrossRef Medline

Rangani RJ, Upadhya MA, Nakhate KT, Kokare DM, Subhedar NK (2012) Nicotine evoked improvement in learning and memory is mediated through NPY Y1 receptors in rat model of Alzheimer's disease. Peptides 33:317-328. CrossRef Medline

Rose JB, Crews L, Rockenstein E, Adame A, Mante M, Hersh LB, Gage FH, Spencer B, Potkar R, Marr RA, Masliah E (2009) Neuropeptide Y fragments derived from neprilysin processing are neuroprotective in a transgenic model of Alzheimer's disease. J Neurosci 29:1115-1125. CrossRef Medline

Ryan DA, Narrow WC, Federoff HJ, Bowers WJ (2010) An improved method for generating consistent soluble amyloid-beta oligomer preparations for in vitro neurotoxicity studies. J Neurosci Methods 190:171179. CrossRef Medline

Saito T, Matsuba Y, Mihira N, Takano J, Nilsson P, Itohara S, Iwata N, Saido TC (2014) Single App knock-in mouse models of Alzheimer's disease. Nat Neurosci 17:661-663. CrossRef Medline

Sakakibara H, Suzuki A, Kobayashi A, Motoyama K, Matsui A, Sayama K, Kato A, Ohashi N, Akimoto M, Nakayama T, Shimoi K (2012) Social isolation stress induces hepatic hypertrophy in C57BL/6J mice. J Toxicol Sci 37:1071-1076. CrossRef Medline

Saper CB, German DC (1987) Hypothalamic pathology in Alzheimer's disease. Neurosci Lett 74:364-370. CrossRef Medline

Schupf N, Tang MX, Fukuyama H, Manly J, Andrews H, Mehta P, Ravetch J, Mayeux R (2008) Peripheral Abeta subspecies as risk biomarkers of Alzheimer's disease. Proc Natl Acad Sci U S A 105:14052-14057. CrossRef Medline

Sperling RA, Aisen PS, Beckett LA, Bennett DA, Craft S, Fagan AM, Iwatsubo T, Jack CR Jr, Kaye J, Montine TJ, Park DC, Reiman EM, Rowe CC,
Siemers E, Stern Y, Yaffe K, Carrillo MC, Thies B, Morrison-Bogorad M, Wagster MV, et al. (2011) Toward defining the preclinical stages of Alzheimer's disease: recommendations from the National Institute on Aging-Alzheimer's Association workgroups on diagnostic guidelines for Alzheimer's disease. Alzheimers Dement 7:280-292. CrossRef Medline

Stewart R, Masaki K, Xue QL, Peila R, Petrovitch H, White LR, Launer LJ (2005) A 32-year prospective study of change in body weight and incident dementia: the Honolulu-Asia Aging Study. Arch Neurol 62:55-60. CrossRef Medline

Takeda S, Sato N, Uchio-Yamada K, Sawada K, Kunieda T, Takeuchi D, Kurinami H, Shinohara M, Rakugi H, Morishita R (2010) Diabetesaccelerated memory dysfunction via cerebrovascular inflammation and Abeta deposition in an Alzheimer mouse model with diabetes. Proc Natl Acad Sci U S A 107:7036-7041. CrossRef Medline

van den Pol AN, Yao Y, Fu LY, Foo K, Huang H, Coppari R, Lowell BB, Broberger C (2009) Neuromedin B and gastrin-releasing peptide excite arcuate nucleus neuropeptide $\mathrm{Y}$ neurons in a novel transgenic mouse expressing strong Renilla green fluorescent protein in NPY neurons. J Neurosci 29:4622-4639. CrossRef Medline

van den Top M, Lee K, Whyment AD, Blanks AM, Spanswick D (2004) Orexigen-sensitive NPY/AgRP pacemaker neurons in the hypothalamic arcuate nucleus. Nat Neurosci 7:493-494. CrossRef Medline

Vidoni ED, Townley RA, Honea RA, Burns JM; Alzheimer's Disease Neuroimaging Initiative (2011) Alzheimer disease biomarkers are associated with body mass index. Neurology 77:1913-1920. CrossRef Medline

Wang G, Coleman CG, Chan J, Faraco G, Marques-Lopes J, Milner TA, Guruju MR, Anrather J, Davisson RL, Iadecola C, Pickel VM (2013) Angiotensin II slow-pressor hypertension enhances NMDA currents and NOX2-dependent superoxide production in hypothalamic paraventricular neurons. Am J Physiol Regul Integr Comp Physiol 304:R1096-R1106. CrossRef Medline

White H, Pieper C, Schmader K (1998) The association of weight change in Alzheimer's disease with severity of disease and mortality: a longitudinal analysis. J Am Geriatr Soc 46:1223-1227. Medline

Zhang Y, Proenca R, Maffei M, Barone M, Leopold L, Friedman JM (1994) Positional cloning of the mouse obese gene and its human homologue. Nature 372:425-432. CrossRef Medline

Zhang Y, Zhou B, Deng B, Zhang F, Wu J, Wang Y, Le Y, Zhai Q (2013) Amyloid- $\beta$ induces hepatic insulin resistance in vivo via JAK2. Diabetes 62:1159-1166. CrossRef Medline 